Article

\title{
'Uncovering the Self': Religious Doubts, Spirituality and Unveiling in Egypt
}

\author{
Karin van Nieuwkerk
}

check for updates

Citation: van Nieuwkerk, Karin. 2021. 'Uncovering the Self': Religious Doubts, Spirituality and Unveiling in Egypt. Religions 12: 20. https:// doi.org/10.3390/rel12010020

Received: 27 November 2020 Accepted: 23 December 2020 Published: 28 December 2020

Publisher's Note: MDPI stays neutral with regard to jurisdictional claims in published maps and institutional affiliations.

Copyright: (C) 2020 by the author. Licensee MDPI, Basel, Switzerland. This article is an open access article distributed under the terms and conditions of the Creative Commons Attribution (CC BY) license (https: / / creativecommons.org/ licenses/by/4.0/).
Faculty of Philosophy, Theology and Religious Studies, Radboud University, 6525 XZ Nijmegen, The Netherlands; k.vannieuwkerk@ftr.ru.nl

\begin{abstract}
Since the 1980s, discourse on religious piety has taken many different forms, from mosque lessons by lay preachers—such as 'Amr Khalid—to religious TV programmes and leisure activities. Within this widespread religious culture and cultivation of forms of visible piety, wearing the veil became an almost uncontested norm for women. As Saba Mahmood demonstrated, the veil became a crucial way to express and cultivate a 'pious self'. Yet especially since the 2011 revolution and its aftermath, many young Egyptians started to question political, religious and patriarchal authorities. Amongst others, this took on open or hidden forms of non-believing, as well as a search for new forms of spirituality. Based on fieldwork and interviews, this contribution looks into the motives and experiences of women who decided to cast off the veil. In view of the hegemonic piety discourse, this is a huge issue, which is met by fierce reactions and accusations of immorality and non-belief. Whereas for some women this decision is an expression of religious doubt or a turn to a non-religious worldview, for others it is a way to contest the current piety discourse in a search for a more personal and spiritual connection with God. While the relationship with religion among my interlocutors might differ, they share a common attempt to uncover their 'authentic selves'. By unveiling, they express their wish to define their own space and ideas regarding religion, gender and their bodies.
\end{abstract}

Keywords: (un)veiling; gender; spirituality; piety; non-belief; the self; Islam; Egypt

\section{Introduction}

"'Amr Khalid ruined my childhood", Heba mentions several times during the interview I conducted with her in a smoky coffee shop in an upmarket neighbourhood in Cairo. "Because wearing hijab at the age of twelve ( . . ) entails many other things, such as, you are not allowed to play in the streets anymore; you're wearing hijab so you better not run $(\ldots)$ because your boobs would shake $(\ldots)$. Hijab is so un-feminist! ( . . ) It is so discriminatory! ( . . ) You become so judgmental ( . . ) Hijab makes people view themselves as if they are morally better, even if they're not".

In front of me sat a passionate young woman of 24 with her attractive long curly hair loose, confidently talking about her current views on religion and gender, as well as the pain she endured during the process of removing the hijab. Although she "hates" "Amr Khalid, the popular lay preacher who was highly influential in spreading the piety movement into the middle and upper-middle classes from the 1990s until the 2011 revolution, taking off the veil in no way signalled a decrease in devotion: "I can tell you wholeheartedly that when I removed this [hijab], I became so close to God!".

The hardship she endured was particularly related to the strong opposition of her relatives, especially the 'emotional blackmail' of her mother. By unveiling, doubt was raised regarding her morality and faith, whilst it also endangered her family's reputation due to the suspicion that they were not raising her as a properly marriageable girl.

1 All names have been changed. Interview with author on 11 January 2019. 
Women's bodies have often been the terrain over which social, religious and political views have been contested, enforced or reclaimed. Since the 1990s' 'Islamic Revival', the piety movement crafted 'pious and disciplined bodies'. The 2011 revolution, however, seems to have opened up space for 'liberated bodies'. The younger generation of the revolution not only questioned the political establishment, but also religious and patriarchal authorities. It unleashed a search for the younger generation's own voice and ways of life. Several women I interviewed in the course of my research on religious doubts and unveiling expressed that wearing hijab 'is not the natural $\mathrm{me}^{\prime} .^{2}$ Their experiences with and through the revolution bolstered their courage to reclaim their own bodies and minds. They wanted to "own" their bodies and minds. While the political revolution is felt to have 'failed', a 'silent revolution' appears to be ongoing. ${ }^{3}$

Yet, we should be careful not to replicate the oppositions that have harmed the field of anthropology of Islam for too long, in which Islam is equalled to cultivating docile bodies whereas developing non-religious sensibilities would entail agency and liberation. As Saba Mahmood articulated, agency is the historically and culturally specific modality of action to effect changes in the world and in oneself. What appears docile (or liberated) are forms of agency "... that can be understood only from within the discourses and structure of subordination that create the conditions of its enactment" (Mahmood 2005, p. 15). The revolution appears to have enabled new modalities of action and to have opened up space to question religious, political and patriarchal authorities (Van Nieuwkerk 2018b, 2021a). Although most of my interlocutors were pessimistic about the current possibilities to effect change 'in the world', they acknowledged the changes that have been stimulated within 'themselves'. It is thus important to contextualise (un)veiling as a form of agency in the changing political and religious landscape of Egypt.

This article will closely consider unveiling in present-day Egypt (see Kütük-Kuriş for a comparative case study on Turkey, this issue). Some of my interlocutors were non-religious and removing the veil was a way to embody and express their non-religious lifestyles. For others, taking off the hijab was part of their journey towards a more inward-focused or personal form of piety and spirituality. Studying the process of unveiling can thus twin the religious and non-religious motivations of women rather than opposing them. While the relationship with Islam among my interlocutors might differ, they share a common attempt to discover their own personalities and identities. By unveiling, they express their wish to define their own space and ideas regarding religion, gender relations, femininity and their bodies. Unveiling is not only about religion, but particularly about 'uncovering their selves'.

Based on fieldwork and interviews, ${ }^{4}$ this article examines the motivations and experiences of women who decided to remove the veil. For the larger project on religious doubt and non-belief, I conducted several periods of fieldwork between 2013 and 2018. I interviewed 37 non-believers, ranging from agnostics to outspoken atheists, consisting of 22 males and 15 females of which 26 were former Muslims and 11 former Copts. I also investigated the state media on atheism and the social media generated by activist atheists. In that context I interviewed ten women who took off the veil. I also spoke with three women who unveiled but remained spiritual. This is why I conducted an additional seven

2 See Section 5. on unveiling and uncovering the self for an explanation of the different voices regarding finding "me".

3 For the notion of 'silent revolution', see: http:/ / www.eutopiamagazine.eu/en/ayman-abdelmeguid/columns/egypt $\backslash \mathrm{T} 1 \backslash$ textquoterights-silentrevolution.html (accessed on 10 June 2015). For more information about the connection of religious doubts and the revolution, see Van Nieuwkerk (2021a) and also the Introduction to this special issue.

4 The larger project was funded by the University of Kent's Understanding Unbelief programme. See for final report https:/ / research.kent.ac.uk/ understandingunbelief/publications-2/understanding-unbelief-in-egypt/. In addition to the 20 interviews, I also conducted two interviews with veiled women about the phenomenon of unveiling and used social media material. See, e.g., the following sources accessed on 14 April 2020 : You tube channel 'Black Duck' by atheist Ismail Mohamed https://www.youtube.com/channel/UCQuIOUMM0WaUXnlyEuo-6Ng/featured (particularly episode 45 Interview with Reem, no longer available). https://www.nytimes.com/2015/04/11/opinion/mona-eltahawy-myunveiling-ceremony.html; https://www.youtube.com/watch?v=Lj9vRlQ5Omg; See also Eltahawi (2016); https://www.youtube.com/watch?v= 2atV258ED1w; https: / / www.youtube.com/watch?v=b9wejmiT-6Q; https:/ / stepfeed.com/we-talked-to-women-who-took-off-the-hijab-0308; https:/ / www.posifitivy.com/blog/2019/1/11/on-women-removing-their-hijab. All material was analysed and coded in Atlas ti. 
in-depth interviews with women who remained within the faith but unveiled in January 2019. Accordingly I interviewed twenty women between 2015 and 2019, of whom 10 self-identified as non-religious and 10 as either spiritual or Muslim. During the research on religious doubt and non-believing, unveiling was only one of the many aspects that were significant in their trajectories and for this reason these interviews less richly document the process of unveiling itself. I mainly used a snowball technique to access women, since the topic, particularly doubt and non-religion, is very sensitive. Therefore, only trusted friends could introduce me to a next interlocutor. Most women I interviewed were between 25 and 35 and of middle or sometimes upper-middle class backgrounds. All were highly educated and worked in journalism, with NGOs, in teaching or translation work or international companies. They were young urban professionals. Accordingly my results are not representative for the experiences of women of other social classes in Egypt.

By analysing young urban professional women's experiences with unveiling in present-day Egypt, I hope to contribute ethnographically to an 'anthropology of Islam, doubt and (non) religion'. The first section will examine the anthropology of Islam, doubt and non-belief. The second section will analyse the historical developments regarding (un)veiling in Egypt and the theoretical lenses used to explain this phenomenon since the 1970s. Section three highlights the motivations of my interlocutors to veil and the following section, section four, why they choose to unveil. This article will particularly demonstrate the ways in which my interlocutors reclaim their minds, bodies and 'selves' by unveiling.

\section{The Anthropology of Islam and Non-Belief}

Saba Mahmood (2005), Charles Hirschkind (2006) and others-inspired by Talal Asad (2003) — centred their attention on the Islamic Revival in Egypt, followed by numerous studies working on Egypt or other parts of the Muslim world (e.g., Hafez 2003; Jouili and Amir-Moazami 2006). Their studies were ground breaking for several reasons. They took the religious motivations, desires and practices that became visible in Egypt since the 1980s seriously as a religious phenomenon in their own right. Rather than reducing it to a reaction to Westernisation or as political statements against secularising regimes and economic malaise, Islamic piety was studied for its own intrinsic motivating force.

Authors such as Mahmood and Hirschkind also demonstrated how people were cultivating a pious self by veiling, by listening to religious Qur'an recitations, by acquiring Islamic knowledge through courses and lectures, by praying and by various other religious practices characteristic of the piety movement. These religious activities were a means of training the religious sensibilities of the participants of the piety movement. Mahmood and Hirschkind turned the common notion that praying is an expression of devotion upside down and showed how praying and other religious acts helped to hone a pious constitution.

Moreover, particularly Mahmood (2001) also showed that cultivating a pious self is an active ethical process performed by devotees. Agency should not only be conceptualised as a form of resistance towards religion and normative structures. Conforming to and trying to adhere to religious norms also needs active training and struggle.

This brief summary only scratches the surface of the new paradigm that these authors have introduced into the anthropology of Islam. Yet several authors also criticised the 'pious turn' in anthropology, also known under the umbrella question "is there too much Islam in the anthropology of Islam" (Schielke 2010, p. 1).

First, several authors working on women's roles in the piety movements around the world criticised Mahmood's analysis of 'submission' or conformity to religious prescriptions as an active way to cultivate piety-albeit inspiring — as one sided, since it started to elide other forms of agency by pious women, such as resistance (Noor 2017).

Second, scholars draw attention to ambivalence, doubt and ambiguity in everyday life practices, including in religious practices. As Schielke argues, the studies on the piety movement tended to present an image which is "too coherent and idealised". Not only are the religiously-committed individuals easily taken as "paradigmatic representatives", scholars also tend to analyse attempts to realise a pious self, rather than the actual outcome 
of the endeavours. Further, by taking exceptional, committed activists rather than the majority of people as the basis of analysis, these studies tend to reproduce the bias of the specific group under study (Schielke 2009, p. 537). Schielke and Debevec (2012, pp. 23) argue: " ... for a view that takes ( . . ) everyday practice ( . . ) of religion as the starting point, looking at actual lived experiences and their existential significance for the people involved."

Third, the larger background to these lines of critique on the pious turn is shaped by the societal and academic discourse on Islam and Muslim societies. These tend to perceive 'Muslims' foremost as religious subjects as if they only devote themselves to religious activities. Inadvertently, the pious turn might produce an account of Islam that is very much in line with social and political discourses on Islam as a dominant feature and force that cannot be erased. As Schielke observed on the pious turn: "While this turn has provided direction for a number of innovative studies, it appears to stop short of some key questions regarding everyday religious and moral practice, notably the ambivalence, the inconsistencies and the openness of people's lives that never fit into the framework of a single tradition. In short, there is too much Islam in the anthropology of Islam (Schielke 2010, p. 1)."

Finally, Makdisi argues that the copious scholarship produced about Islam including the works by Asad and Mahmood leave out the abundant, obvious and meaningful discourses and practices of non-Muslim Arabs and secular Arabs: "I concur with Aziz al-Azmeh's criticism of the "over-Islamization of Islam." The fixation on the study of "Islam", "the Muslim", "the Muslim Women" and "Islamic piety" has ignored secular Arabs or those Muslim Arabs for whom piety does not signify something publicly political (Makdisi 2019, p. 16)."

Two promising lines of inquiry can be deduced from these critical observations: a focus on the study of everyday life and its ambivalence; and examining the secular and non-Muslim traditions in the 'Islamicate' world (Hodgson 1974).

The line of inquiry into the 'everyday life' and its ambiguities is important and promising. Yet, scholars need to be careful to avoid (re)creating a tension between the normative realm and the everyday life as Fadil and Fernando (2015) have observed. In their attempt to think through this new investment in the 'everyday', they observe that some proponents of the study of everyday life might inadvertently claim that religion belongs to the normative realm, whereas play or ambiguity in the practice of religion is part of the realm of everyday life. Daily life is then solely examined as the site where religion is resisted. Yet religious deliberations on norms and practices take place at both the level of normative traditions and in daily life. Indeed, as I will show, the process of (un)veiling includes deliberations in everyday life about religious normative discourse and practices as well as resistance, doubt and reconsideration of these norms and practices. 'Grand schemes' - in this case foremost the religious discourse promoted by the Egyptian piety movement-and 'the everyday' are not opposed, but integrated into daily life's deliberations and practices.

The second line of inquiry - studying the traditions of non-Muslim Arabs (Christians, Jews, etc.), secularism, secular sensibilities (Hirschkind 2010), religious doubt (Pelkmans 2013), non-religious people from diverse denominational backgrounds, etc.- - is relevant in a historical sense as well as timely, as there appears to be a trend towards increased religious doubt and non-belief (Whitaker 2014, Arab Barometer). ${ }^{5}$ However, this line of inquiry is not yet well developed. Due to the same bias to view Islam/religion as a dominant force, secularism and non-believing has received scant attention (Makdisi 2019; Van Nieuwkerk 2018c). Whereas religious discourses on apostasy and legal aspects have received attention (e.g., Adang et al. 2016; Olsson 2008; Larsson 2018), the number of studies on embodiment

5 https://www.arabbarometer.org/survey-data/data-analysis-tool/ (accessed on 7 October 2019). See also https:/ / www.bbc.com/news/worldmiddle-east-48703377. 
and daily life experiences of non-believers are limited and have only recently started to emerge. ${ }^{6}$

In the study of non-belief and atheism in general (not necessarily related to Islam), the focus appears to be on leaving 'religion'. ${ }^{7}$ That is, they mainly express a 'religio-centric' perspective (Streib 2014; Cragun and Hammer 2011; Lee 2015). In line with Schielke (2010), who argues that there is too much Islam in the anthropology of Islam, it could be argued that there is also too much emphasis on religion in the process of moving out of Islam. Of course we should study theological doubts and motivations, but the process of leaving a faith entails much more than the religious or doctrinal aspects. Moving out of Islam can be only a small part or specific stage in the enfolding life stories of people.

I concur with the argument that it is important to study the everyday life negotiations of normative traditions, whether religious or informed by other 'grand narratives' (e.g., secular-liberal ideologies), and how these discourses are appropriated, reproduced and transformed in people's lives. I also think we should not only study paradigmatic examples, whether in processes of religious intensification or in leaving religion. Just as cultivation of the pious self needs training and effort, the same holds for secular sensibilities. It is important to study the enactment of belief and non-belief in terms of embodiment, affect, dressing and changing daily life practices such as eating and feasting. Neither belief nor non-belief is a 'natural' or 'normal' disposition, but needs cultivation.

This article will investigate unveiling as a lens through which to apply this research approach. I consider unveiling is a suitable topic to do this, first because dress and comportment are significant aspects of daily life. Second, as is examined below, unveiling is part of the project of religious questioning and leaving faith, as well as searching for an inward-focused, individualised piety. Therefore, both belief and non-religiosity can be considered within the single study rather than setting these out as two separate fields. By not a priori opposing the 'believers' to the 'non-believers', I was able to closely examine the profound communalities in my interlocutors' journeys with (un)veiling. Third, unveiling discloses women's active engagement in uncovering and cultivating the self. Akin to cultivating a pious self by veiling, unveiling is for a large part about discovering the self in its multifaceted aspects. Finally, whether unveiling for spiritual or non-religious reasons, the motivations extend beyond a narrow focus on religion per se into the questioning of gender and subjectivity. Accordingly, the study of unveiling can critically question the salience of religion as a motivating factor and force in women's lives and aspirations.

The phenomenon of (un)veiling in Egypt and the different theoretical frames that have been used to study it within their historical and shifting contexts will be examined in the next section. All of these frames have been relevant for certain periods and pertain to specific groups of Egyptian women.

\section{Understanding Veiling in Egypt since the 1970s}

Veiling by women is and was the most notable aspect of the Islamic Revival since the 1970s. It is a rich topic that has been debated since the beginning of the last century when the first Egyptian women removed the face veil. Most scholars agree that the veil of the 1970s is not a re-appearance of the veil that elite women once wore up until the beginning of the 20th century. It is a new phenomenon with new meanings.

In 1983, I lived on campus at Cairo University for 10 months and had lengthy discussions with many students, half of whom had recently adopted the veil. Many unveiled students intended to veil at a later point in their lives. MacLeod mentioned a consistent growth of veiling among lower-middle-class working women from about one-third of her informants in 1983 to three-quarters in 1988 (MacLeod 1991, p. 105). Sherifa Zuhur's

6 See Schielke $(2012,2013)$ and Van Nieuwkerk (2018a, 2018b, 2021a, 2021b) for Egypt; Enstedt (2018) for Muslims in Sweden; Cottee (2015), for Muslim in the UK and Canada; Vliek (2020) for Muslims in the UK and the Netherlands.

7 For the notion of becoming an 'ex', see Ebaugh (1988). On leaving Religion, see Handbook of Leaving Religion (Enstedt et al. 2020) (https: //brill.com/view/title/33911). 
research took place in 1988 and two-thirds of her informants were veiled, either with a hijab or niqab; the face veil (Zuhur 1992, p. 59). During my last research before the revolution, most people estimated that approximately 80 to 90 per cent of Muslim women in Cairo were veiled. Whereas this is not necessarily based on accurate statistics, it conveys the notion that an overwhelming majority of Muslim women were veiled. Non-veiled women were often assumed to be Copts.

In the 2010s, some analysts note a trend towards 'down-veiling', which "refers to a subtle and seemingly growing tendency among certain circles of urban Egyptian women toward less concealing and less conservative forms of Islamic dress" (Herrera 2001, p. 16). In addition, the development of fashionable styles of veiling started to become visible. Veiled artists and TV personalities played a prominent role in making veiling fashionable (Van Nieuwkerk 2013). As well as the trend towards down-veiling, there seemed to be a trend towards 'up-veiling' running in parallel. The niqab also attracted a growing number of adherents in the urban landscape. With most women wearing a more or less stylish form of veiling, the veil as such lost its clear message of piety and modesty. The veil had fallen victim to 'piety inflation', with some pious women trying to distinguish themselves by wearing the niqab (Van Nieuwkerk 2013).

Yet around the time of the revolution (2011), several women started to reflect on the veil and whether this was a conscious personal choice or merely one based on peer pressure. Again, no numbers or statistics are available, but especially the middle-class and well-educated women I talked to recently (2015-2019) mention many friends or friends of friends who either removed the veil or wanted to do so but were afraid of the potential repercussions. The story of unveiling was occasionally shared on Facebook and some stories were published (Eltahawi 2016). It is now more common to see unveiled women in upmarket neighbourhoods.

There are several theoretical frames for understanding veiling in Egypt, which have evolved over time. In the late 1970s, scholars focused mostly on socio-political aspects and conceptualised veiling as a form of protest or activism (El-Guindi 1981, 1983; Marsot 1984; Hoffman-Ladd 1987; MacLeod 1991). The first studies on veiling as activism mainly concentrated on female university campus students in the late 1970s. Veiling, perceived as the symbol of Islamic authenticity, was theorised as a form of protest whether against the secular regime or against cultural dominance by the West.

In the 1980s, several authors understood veiling as the symbol of tradition and submission. It was analysed as the public evidence that women had internalised and accepted control over their bodies and sexuality. An interesting analytical mixture of submission and protest was developed by MacLeod (1991). She conducted her research among lower-class working women. For these women the hijab was a form of symbolic action by which they expressed their feelings of conflict and confusion about combining work outside the home with marriage and motherhood (MacLeod 1991, p. 97). Although lower-class working women were out and about in public, according to MacLeod, they actually felt that their main place should be in the house. By veiling, they signalled to neighbours, colleagues and strangers in the street that their primary role was that of a "traditional wife and mother" (MacLeod 1991, p. 121).

From the late 1990s onwards, a focus on the religious meaning of the veil as a sign of piety surfaced as a main frame to understand veiling (Mahmood 2001, 2005; Deeb 2006). Researchers studying the veil in the late 1990s criticised previous studies for their lack of attention to the religious dimensions of veiling (Deeb 2006; Mahmood 2001, 2005). Mahmood $(2001,2005)$ in particular studied the role of veiling in creating a pious self. According to preachers of the piety movement, veiling should not be seen as a custom but as "a challenge that far exceeds the simple act of donning the veil" (Mahmood 2005, p. 51). Veiling is a critical marker of piety, as well as the "means by which one trains oneself to be pious" (Mahmood 2005, p. 158). The veiled body becomes the "necessary means through which the virtue of modesty is both created and expressed" (Mahmood 2005, p. 23). Veiling 
can be compared to praying, reading Qur'an or engaging in charity. It is one of the means to construct a pious self which simultaneously expresses and harbours the feeling of piety.

Not only has the religious meaning and motivations of veiling spread more widely since the late 1990s, but the pious discourse on veiling has also become more elaborate and wide spread across various classes in Egypt. With the growth of the piety movement, many women took lessons in the mosque and familiarised themselves with the religious discourse of this movement. Lay preachers, such as 'Amr Khalid, with their clean-shaven faces, modern appearances and pleasant messages that piety and wealth could sit well together (Bayat 2002; Wise 2003), attracted young people and the well to do. Veiling was also an important topic among the female preachers who gave lectures in the many 'Islamic salons' at the homes of the upper-middle classes. The growing religiosity among the upper classes and 'lighter' religious discourse are among the factors that encouraged the development of veiling as a fashion item. Veiling, in whatever form, became the new normal among large segments of society (Van Nieuwkerk 2013).

The 2011 revolution was a watershed experience for many, especially the young. Many younger Egyptians started to question political, religious and patriarchal authorities, the three interconnected and seemingly unassailable powers that once one showed signs of crumbling, did not leave the other two untouched. The political regime, backed by religious authorities and some of the lay preachers (such as 'Amr Khalid), lost credibility. The politicisation of Islam and the ensuing power play during and after the revolution also contaminated religious discourses. This was compounded by the one-year rule of the Muslim Brotherhood, which proved a conduit for doubts about the credibility of Islam as a political system. The Muslim Brotherhood's maxim 'Islam is the solution' fell totally flat with a section of the younger generation.

Loosing fear of the ruling power and its repressive apparatus was a significantly empowering experience. It also enabled the questioning of different kinds of authorities, as a young female non-believer who unveiled, Elham, explained to me: ${ }^{8}$

Any person under 30 and anyone born up to until 1981-any Egyptian-came to consciousness knowing one thing: Hosni Mubarak is the president. He was a part of the hierarchy. 'Okay there's God, there's religion and there's also Hosni'. And we couldn't change him, whatever happened. Being able not only to say no, but to say no in these huge numbers and to actually throw him out of his position made people think... well, if he can go, then any authority can go! What about the authority of God?

Ibtisam similarly explained how this feeling of empowerment during the revolution and the downfall of Mubarak quickly boiled over into questioning religious authority:

That's what I like about the revolution. It could be a collective experience and at the same time a very personal one. After the revolution I was still wearing the hijab. Then I started to question not just Islam, but the notion of God himself. I compared him to the president, to tyranny, God as tyrant. Somebody is in charge all the time; you're never free. Even if you think you're free. For me this was the starting point. ${ }^{9}$

As can be seen in greater detail in my interlocutors' narratives below, the revolution was a catalyst not only to question political, religious and parental authorities, but also to uncover and free 'the self' from these powerful authoritative discourses (see also Introduction, this issue). However, their motives to veil are examined first.

\section{Motives to Veil and the Image of Non-Hijabis}

I interviewed twenty women between 2015 and 2019, most within the framework of a larger project on trajectories of religious doubts and non-belief that also included male

\footnotetext{
Interview with author on 29 October 2017.
}

9 Interview with author on 13 February 2015. 
and Coptic interlocutors. Of the twenty interlocutors, two non-religious women had never worn the veil. Sahar used to veil only during the holy month of Ramadan and unveiled the remainder of the year, but later decided to remain unveiled for the whole year. Riham, who has religious doubts and a strong desire to unveil, remained veiled due to concerns about personal security. As a divorced mother she needed to protect her reputation as a respectable mother, in order not to endanger the custody of her daughter. Lina re-veiled due to pressure from her mother and although she was not convinced of veiling herself, she was happy to calm her mother.

Whereas ten identified as Muslim-spiritual believers, the other half were either agnostic, atheist or identified as both spiritual and as non-religious. They believe in 'God' or a 'force', but not necessarily in religion or in the Muslim conception of God as they had been taught. This indicates not only the complexities in the relationship between (un)veiling and religious identifications, it also reflects the difficulty in drawing firm lines between belief versus non-belief, as many of them remain spiritual whether within or beyond the self-defined boundaries of Islam. ${ }^{10}$

Most of my interlocutors did not characterise their upbringing as strict, but rather as conservative. Heba, with whom I started the introduction, explained what a conservative religious family entails:

As a child I was so religious. So devoted! I'm basically brought up in a semi, kind of, conservative family. Not extremist, but conservative: who like their girls modest; who like them not to have relationships with boys at school and stuff like that. To be modest in your clothes, in your talking... ${ }^{11}$

Karima was from a 'sharif' family, that is, she is related to the lineage of Prophet Muhammad, but described her family as moderate. Three of them considered their families 'strict'. Zahra, who had never donned the veil, came from a communist family and had as a child been scared to death that her friends would discover that her parents were non-believers.

It was not uncommon for my interlocutors-whether from a religious, conservative or moderate family - to go through a period of religious intensification. Elham, who has now left Islam, explained:

My upbringing was really very religious. ( . . ) Hijab is a nice thing for women. Prayers always are the way we connect to God and beware of everything you say and everything you do, because it may upset God. As a child I was very afraid of this thing that they called God that I don't know. I even imagined him as a very giant man, with a very long beard [laughs]. I know this is really childish, but this is how I imagined him. Very angry and ready to throw me in hell at any point-whatever I do he might anyway send me to hell. ( . . . ) But as a teenager, I don't know what happened, I became really very religious. I even prayed more often and I went to the mosque more often. I talked to people like I am a sheikh [laughs] or a da'iyya [preacher]. ${ }^{12}$

Hayat also related that-against the wishes of her parents—she went through a period of religious intensification when she was 16:

I started with an upbringing in which there was not that much religion but more morals $\left(a k h l a^{\prime}\right)$. I am the one who went in the direction of religion. It was my personal decision. My parents did not agree. I decided to wear the veil. I was convinced that I had to wear the hijab because it was a religious duty ( ... ). I wanted good credits (sawab). My parents refused the veil because I was still young. ( . . . ) I wore the veil because of my religiosity and extremism [tadayun wa

10 I will focus on unveiling and for that reason cannot deal with the complete stories of leaving Islam of my non-religious interlocutors. See for more on non-belief Van Nieuwkerk (2018a, 2018b, 2021a, 2021b).

11 Interview with author on 11 January 2019.

12 Interview with author on 29 October 2017. 
tazamud] ( . . . ) I was worshipping God, reading Qur'an and hadith and listened to sheikhs. I did not even greet a man. I wanted to wear the niqab, but my father objected completely to this. ${ }^{13}$

Even Zahra from the communist family 'tried religion':

I tried to fast for a couple of years, not out of being convinced but out of trying to fit in. To see what they see, to feel what they feel, to be like them. Maybe they have a point, maybe they see something that I don't see, maybe it is because of my upbringing that I don't see it. (...) But (...) it did not have any meaning for me [laughs]. ${ }^{14}$

In the three previous quotes, my interlocutors refer to key aspects-or 'grand schemes' -of the religious revival in which they grew up: being afraid of hell and the afterlife, trying to earn religious credits for the hereafter (sawab) and foremost devotion through hijab and modesty for women. But when this discourse becomes the 'norm', 'fitting in' also becomes important.

Popular lay preachers, influential in the piety movement of the 1990s, emphasised the importance of being ready for the afterlife and for 'meeting your Creator' (Van Nieuwkerk 2013). Hijab was an imperative preparation for this, as Karima from the sharif lineage of the Prophet explained:

... we as young people back then, we were 15 and 14 and we were thinking of il-akhra, the afterlife. So that is why basically, most-if not all-the girls wore it [hijab] at that time: because they are afraid of the afterlife: (...) 'Let's hope and work for it and do whatever sacrifices for the afterlife'. ( . . ) It was the fear of the afterlife, the fear of being punished, because of what you were wearing, you were doing, or you were not doing ... 15

Even if you did not personally listen to the preachers' tapes, the pious discourse on the afterlife and the importance of veiling would reach you via friends, Karima continues: "I did not personally listen to these very famous videos or cassettes ( . . ) but my friends would tell ( . . ) stories about how a bride on her wedding day was not wearing it and in full make up and suddenly a car hit her and 'Oh my God! You can die at any moment'."

Sahar, who used to veil only during Ramadan, was confronted with scary discourses on not wearing hijab while at high school:

(... ) there was a teacher who spoke to us about heaven and hell and death and torture and that kind of stuff and I developed a very severe phobia of death from high school. Because I am not veiled, the male teachers would take it upon themselves to start preaching. One of them said something to me that I will never forget. 'You are walking on the rope now but fire is around you, hell is walking around you', because I was not veiled. It really scared me back then. Deep down I thought God is probably not that narrow minded, but at the same time it scared me because I thought it must be true. ${ }^{16}$

Being raised with the hijab discourse circulating within the piety movement, it was sometimes difficult to disentangle whether veiling was a personal choice or one also influenced by social, religious or peer pressure. For Arya, it felt like her own choice at the age of 15, yet she also acknowledges 'indirect pressure':

Yes, at the time it was my choice (... ) Maybe pressured indirectly, because of the circles around you. Because most of the friends just put it on, so you need to be like them (...) But for me (...) it was completely my choice. I was really happy about it at the time. (... ) Everything was right after Ramadan. So, you

13 Interview with author on 15 February 2015. It was conducted mostly in Arabic but we changed into English as soon as the waiter was near.

14 Interview with author on 30 October 2017.

15 Interview with author on 12 January 2019.

16 Interview with author on 28 April 2018. 
know, you just feel spiritually you are ready for this. And you are feeling 'ahh, it is time'. ${ }^{17}$

Yet, several of my interlocutors explained how although at the time it felt like a personal choice - and not an easy one at that-in hindsight they see that it was also informed by 'encouragement from the environment to veil' or to do with 'fitting in'. Heba, for instance, explains that she was a rebel by nature by veiling at a very young age of 12: "So I was like the one standing out. I am doing the adult thing, that was wearing hijab." She also reflects that it was neither choice nor force:

( ... ) No, it wasn't my choice. I wasn't forced to do this, but because of the environment I was in. It was so encouraging to do this. The notion of the more you cover up, the closer you are to God; a very specific notion. The way you dress speaks about your beliefs, your upbringing; that you actually come from a very good family. ${ }^{18}$

Ibtisam, who only donned the veil for two years, explained that she did not veil for intrinsic pious reasons but "because society was telling that in order to be closer to God you need to wear hijab. I was young and all my friends were wearing hijab. I went with the flow." Others also explained that they veiled because they were praised and loved for doing so and were told that "God loves the veiled girls". Riham, who wants to remove the veil but tries not to taint her image as a respectable mother after divorcing, explains:

I was not for it or against it. It was just something that everybody was doing. Especially after the 'Amr Khalid discourse on hijab, everyone was wearing it and I had to be part of the crowd. Everyone in my class at school was wearing it; they were taking pride and showing it off. And people congratulated the new hijabis. So I followed. ${ }^{19}$

Veiling was therefore inspired by the piety movement and done for pious motives; however, it had also become so much the norm that it became difficult to disentangle piety from peer pressure. Most of my interlocutors do not belong to the 'first generation' youngsters growing up during the piety movement, but are more akin to a 'second generation', as several of them remarked.

The veil became so normal that it started to lose some of its heavier religious symbolism, as Karima from the sharif background explained: “... as you have seen, people are wearing it differently. And we have even invented styles like the Spanish style. And the turban (...) Really cute. (... ) And you can show your earrings and even your neck and everything." When I asked her whether veiling is still interpreted as a religious sign, she continued:

At the beginning it was, that is why we would take care of how we speak with other men, how we wear it. Because you are wearing hijab, you should be presentable or respectful. But now, it's an everyday thing. It's a natural thing; it's like wearing your shoes, it doesn't mean anything. And you will find girls with very tight skinny jeans and even ripped jeans and they are very stylish. ${ }^{20}$

Whereas veiling used to provide some protection against harassment in the street, in my interlocutors' experiences wearing the veil—or not-makes no difference anymore. Harassment made Heba question the hijab: "It happens every day-either verbally or physically. And also, I started to question: Why do I have to accept this despite being so modest? Despite being headscarved?"

Despite the fact that veiling had become the default and that different (fashionable) forms were developing, the religious and moral values attached to the veil in the eyes of

17 Interview with author on 17 January 2019.

18 Interview with author on 11 February 2019.

19 Interview with author on 17 October 2017.

20 Interview with author on 12 January 2019. 
society did not diminish. It signified not only piety or closeness to God, but also being raised in a good family, modesty, good morals and being marriageable. Unveiling was considered an extremely difficult and sensitive issue. Arya explains:

The veil for many people ( ... ) presents your morals. It presents religion; it presents ... your levels of spirituality with God. Although they don't have the right to judge this part ( . . . ). But, [after unveiling] ( . . ) they would feel that you have become less moral, less religious ( ... ), less everything that comes to mind, less... ${ }^{21}$

The combined connotations of 'less religious' and 'less moral' were most frequently mentioned and very difficult to deal with for my interlocutors. Lina, who re-veiled, explained that unveiling is considered a huge sin: "It is the equivalent of converting to another religion. Not believing in God. Having sexual affairs. ( ... ) So for them taking off the veil is a sin, a huge one." 22 Heba explained that after removing hijab some male friends approached her "physically": "you took it off so you are becoming more available to us." ${ }^{23}$

The gravity of unveiling becomes clear by the idea that you better not wear the veil at all rather than veiling and taking it off afterwards, as Karima explained: "This is like you are playing with God. You can't do that. You can't play with God. You have to be serious about it. Because you once wore it, you can't take it off." 24 Latifa is divorced and considers remarrying. Her future husband whom she described as very open-minded asked her to make up her mind whether to veil or unveil, before meeting his parents because "it would give the wrong impression" if Latifa were to remove it at a later date. ${ }^{25}$

Women who unveil are thus considered less religious and less moral and for that reason also less marriageable. Heba was told that her chances of marriage would be minimal as a non-hijabi and her parents want her to marry as soon as possible:

They told me: 'men want a girl who will be the mother of his children and the one who is modest. So your chances of getting married are so minimal right now' (... ). They view me as a less religious person now. So I'm a source of a threat.

(... ) Like they expect me to do anything right now, because you are not wearing hijab. ${ }^{26}$

My interlocutors were also often told that they would be less beautiful without a veil when discussing their wish to unveil with friends and relatives. The beauty of veiling is a well-known aspect of the pious discourse on veiling. The headscarf is sometimes likened to a frame which highlights the attractive features of the face, but it also indicates moral beauty (Van Nieuwkerk 2013).

The image of non-hijabis as less religious, less moral, less attractive and less marriageable is captured in the metaphor Heba heard from the religious institute of al-Azhar where she went to consult on her decision to unveil. The imam she met likened the unveiled lady to "uncovered meat hanging at the butchers full of flies, which you will not be able to eat." Heba was furious at this degrading image of women as butchered meat that cannot be 'consumed'.

Finally, non-hijabis are also perceived as less obedient. They stand out, deviate from society's norms and are perceived as rebellious. Karima explained that after unveiling: "suddenly you are being strange. 'Why are you thinking for yourself? You shouldn't! You should follow the main interpretation that everybody is following ... ' So when you do it,

21 Interview with author on 17 February 2019.

22 Interview with author on 12 January 2019.

23 Interview with author on 11 January 2019.

24 Interview with author on 12 January 2019.

25 Interview with author on 13 January 2019.

26 Interview with author on 11 January 2019. 
it is also threatening to society. Because you are kind of rebelling against what has been established for a couple of decades now." 27

It is against these negative images of non-hijabis that women make the decision to unveil. Unveiling is about going against the grain and an act of rebellion against social and religious discourses on veiling, morality and obedience within the family. They express a claim for more personal space and more air to breathe, as will become clear from my interlocutors' narratives in the next section.

\section{Unveiling and Uncovering the Self}

When I asked Heba whether she remembered the first day she stepped out without a veil she exclaimed: "OH MY GOD. I remember every detail about it." She was told by her parents to uncover only outside their neighbourhood. So Heba went out with a turban covering her hair and met up with a friend who removed it for Heba:

Because she knew of the suffering and the pain I was in. We went to a coffee house (...) and took a lot of pictures, because it is my first day. So my Instagram was ( . . . ) filled with pictures of me. ( . . ) I remember that ( ...) I was very joyful at the beginning of the day, 'I'm free'. I told her like, 'I can't believe I can feel the air in my hair. That is unbelievable; my hair is breathing right now'. (... ) And in the middle of the day, I started to get more uncomfortable. I felt like I was rude. 'I need to bring this back. I need to have my scarf ( . . ) No, I'm not feeling comfortable' ( . . ). This is the kind of damage hijab does: when I removed it, I felt like I'm not covered at all. ( . . ) But, it got better ( . . ) After all I was very, very happy with $m e$; with my choices. ${ }^{28}$

Like Heba, several other of my interlocutors told me about initially "feeling naked" without hijab, a very uncomfortable feeling, but also about "feeling the wind in your hair", a very liberating and enjoyable feeling. Most expressed similar feelings about becoming "me".

As mentioned above, my interlocutors' choices and narratives of unveiling should be situated within the context of the revolution and its aftermath. The revolution empowered people to question political, religious and patriarchal or familial authority structures. Social justice, (gender) equality and more space for alternative lifestyles and personal space outside the control of (parental) authorities and the watchful gaze of society were also core issues. The 'silent revolution'29 that still continues in Egypt is predominantly connected to liberating 'the self' from 'society' and creating an 'authentic self', as my interlocutors' narratives below will further demonstrate.

Most of my interlocutors discuss their emotions just before unveiling in terms of feeling "choked", "I am acting" and "this is not me". Different variations of these expressions are a recurring theme in my interlocutors' stories. Such feelings are related to three interconnected fields: the social ("feeling suffocated"); the religious ("being hypocritical") and the personal ("being true to myself"). The personal dimension particularly includes feelings about femininity.

First, regarding society or community pressure, Arya, for example, described her feelings of being choked both emotionally and physically:

I had this feeling of being choked. ( . . . ) It was a really difficult decision to take it off. ( . . . ) But now I am starting to ... love more of myself. It is not about the people, it is not about your judgments. It is not about your way of thinking. It does not matter anymore to me. ( . . . ) They don't actually want to talk to you

27 Interview with author on 12 January 2019.

28 Interview with author on 11 January 2019.

29 http:/ / www.eutopiamagazine.eu/en/ayman-abdelmeguid/columns/egypt \T1 \textquoterights-silent-revolution.html (accessed on 10 June 2015). See also Van Nieuwkerk (2021a) and the Introduction to this special issue. 
now because 'you are not one of us'. Okay, that is fine! ( . . ) I think I am a stronger person now. ${ }^{30}$

Second, regarding the religious dimensions, Latifa expressed that wearing the veil gave her the "feeling of acting":

It was making me feel like I am acting. So I chose that I was religious, but deep down ( ... I I don't have all the faith. It was very complicated. ( ... ) I need to explore myself. ( . . . ) I just feel like I am not being myself and He knows when I'm acting something that I'm not feeling. It is not right. So, I took it off. And I have never felt happier, freer ( . . . ). I just feel like I am more myself. I feel more religious than ever. ${ }^{31}$

Several of my interlocutors started to feel that in the meantime the hijab has become "just a piece of cloth" and that "hijab does not define a good Muslim". They also reflected on the notion that hijab seems to have become "a free pass": as long as you wear it, you are good in the eyes of society, no matter what your actual behaviour might amount to. Lina also applied this to herself. She was having sexual affairs with boys and having a bit of a "rough time":

So I took it off, because it was not reflecting who I am. It was simply not. And it shouldn't be a free pass. ( . . . ) I am very hypocritical if I pray to God because I am a sinner. I pray because I want to repent. Then I would do it again and have sex again. And then I repent again ( ... ). In 2015, I took the vow that I am not having any affairs with any guy unless he is the right person. (... ) And then I took the veil off. I felt that I treated the veil in my rough patch as a free pass. ${ }^{32}$

Lina felt comforted and accepted by God though, with or without a hijab. Other interlocutors also expressed the feeling that they wanted to be a good person "but not through hijab only".

Another motive to unveil connected to the religious field is that the hijab is felt to create moral distinctions or, as Heba expressed in the quote used to introduce this article, "It is so discriminatory!" Later in the interview I returned to the topic and she reflected:

It discriminates against people, between people. Because ( . . ) it is something that defines you as a Muslim, defines you as something different than the other. $\mathrm{Me}, \mathrm{I}$ 'm the norm and the others are the exceptions. That kind of thing. I hated that in hijab actually, I just hated that. ( . . . ) I remember one day, I was going to work and I woke up, 'Oh my god! I'm doing this again. I'm going to wear this. I don't want to leave the house again with this kind of shape in $\mathrm{me}^{\prime}$. No, it is so damaging. ( . . ) Hijab is ( . . ) so damaging in ( .. ) its core concept. ${ }^{33}$

Several of my interlocutors who not only unveiled but also left religion mentioned this aspect of creating moral distinctions as a core issue that made them question Islam generally. For them it was not only the distinction between the veiled and the unveiled woman but the larger issue of creating distinctions between Muslims and non-Muslims and the claimed moral superiority by Muslims, as they perceive it. Heba reflects on her current stance: "Yeah definitely. I am a person who is less judgmental of people; who is more open to differences; more open to people who are different in terms of religion, in terms of ... race. ( . . ) I'm an advocate for equality between people."34

Third, my interlocutors particularly expressed the notion of finding 'themselves'. Several quotes above already revealed the fundamental connection between unveiling and selfhood: they found their own voice against societal judgement, peer pressure and

30 Interview with author on 17 January 2019.

31 Interview with author on 13 January 2019.

32 Interview with author on 12 January 2019.

33 Interview with author on 11 January 2019.

34 Interview with author on 11 January 2019. 
religious discourse of the piety movement. They developed an individual, personal notion of spirituality - whether within or beyond the religious boundaries of Islam. Some interlocutors mentioned that "hijab is the last thing you should do and not the first" and could imagine re-veiling if they felt that it represented "who they are". Yet they particularly expressed that being religious or spiritual is "between me and God". They sometimes even feel that "hijab creates a distance between me and God" as Heba expresses:

I couldn't handle it. I remember I was praying, I was crying so hard, telling God: 'Please tell me what to do. If this thing is right, make me love it, make me accept it. ( . . ) Because it is actually moving me away from you. (...) I stopped praying. ( . . ) I stopped fasting at Ramadan. I was kind of angry at you. Why you are doing this to me? I'm not loving this'. ${ }^{35}$

For this reason, Heba became "so close to God" after removing hijab. Latifa also explained that after removing hijab: "I just feel like I am more myself. I feel more religious than ever ( ... ). Because I feel so much better, not because I moved away from God, but because I got closer to Him". ${ }^{36}$ For those who remained religious and identified as 'Muslim', the content of their religiosity and spirituality changed not only towards a more personalised form, for some it also changed their conception of God from a frightening force that punishes to a more kind and loving image. Some of them also unburdened themselves from the stress that was placed by the piety movement on death, hell and punishment. Mona, who works for an NGO and self-identifies as atheist, is happy to concentrate on "real pressing issues" such as social inequality rather than worrying about death:

I am happy now when I look into the mirror. Before, I saw someone with a veil that is not me. Before I was sad and feeling guilty all the time. All the time my conscience told me I was sinful: 'He will punish me for a reason'. Now ( ... ) I concentrate on things that I can change in society. And I enjoy my life more. Generally I have become a better person. I no longer think about death all the time. Death is a moment for us all, just a moment like any other. The difference is just that it is the last moment. I am not going to lose years of my life thinking about this moment. ${ }^{37}$

For the non-religious interlocutors the notion of becoming a better person was no longer connected to religion but could be related to different social activities and good conduct. For them, being a moral person had no connection with religion-or even conversely, they were now motivated to do good intrinsically and not out of fear for God. ${ }^{38}$

For all of them, critically using their "own mind" was significant. This could relate to religion but not necessarily so. They expressed that they were no longer "afraid to use their minds". They had no desire "to blindly follow religious authorities", if at all. For some this included questioning hijab as a religious obligation (fard), for others this was one of the many aspects they questioned about religion. Hayat, who self-identifies as agnostic, felt that "Hijab not only made me sit at home, but also cut off my brains from thinking. Even my thinking was of a specific kind; connected with God." Now she felt she created space to reflect on many important social and personal issues. ${ }^{39}$ They generally felt "more open-minded", "less judgmental", and "more world-open".

Finally, for all my interlocutors, religious or non-religious, uncovering their 'selves' by unveiling was also critically related to gender, to their femininity and their bodies. Karima, who works as a university teacher, clearly articulated hijab as 'covering the self' by describing hijab as a "uniform" that erases woman's distinctive personalities:

35 Interview with author on 11 January 2019.

36 Interview with author on 13 January 2019.

37 Interview with author on 16 January 2018.

38 As mentioned before, the relationship with God and Islam is rather different for my religious and non-religious interlocutors. Due to the focus on taking off hijab I cannot go into further detail on why they not only unveiled but also left Islam (See Van Nieuwkerk 2018b, 2021a, 2021b).

39 Interview with author on 15 February 2015. 
We were like unisex. We were neither men nor women. Because this is how the society urges us to be. We were unisex. I look at my students and they are all the same. Unfortunately! Although I know that they have different mentalities and personalities and everything. But eventually they will all wear the same and look the same to me. ( . . ) It [unveiling] makes me aware of myself more; of my uniqueness. ( . . ) It reveals our identities. So it makes me more aware of who I am. ${ }^{40}$

Latifa also reflected that hijabis all look "the same". Although there are different styles: "I just felt we are all the same; copies." 41

For most interlocutors, this uniqueness was related to femininity and sometimes-but not necessarily - 'beauty'. Heba asserted: "I looked far more beautiful when I wore hijab, because hijab frames your features, so you appear more beautiful to be honest. ( . . . ) I was fine either way." 42 As above, the notion of 'veiling as a beautifying frame' is part of the piety discourse as Lina also experienced when she re-veiled. Colleagues told her: "'You look much more loveable' ( ... ). You are much more beautiful. Please don't take it off again'". Yet Lina felt that hijab made her look much older than she actually was. At the age of 18 , she was usually thought to be around $25 .{ }^{43}$ Once again it was particularly related to the feeling that "this is not me", as Latifa also expressed:

I got married really young, right after I graduated. I had my daughter right after I got married. So I started to feel I looked so old. This is when I started to feel ( ... ) this is not really what I would want to feel like. (...) Step by step, I started to feel less feminine, less beautiful: ( . . ) I don't feel old. ( . . ) And then I went through a very difficult time in my marriage. And this was another reason I felt less feminine. And I felt I wanted to take it off. It was around 2010, maybe after the revolution. A lot of people were taking it off. And I started to feel that maybe I need to feel free. I need to feel that I am free. ${ }^{44}$

Latifa even postponed unveiling because she was afraid that people would interpret this as a way to be more attractive to a future husband, whereas for her it was related to feeling and looking like "who she really is". She did feel feminine and did not feel old and she wanted to be free to express these feelings. Sarah likewise did not recognise the image of herself when looking in the mirror when she was pregnant and going out with a hijab: "I looked like a ball with hands. ( . . ) I did not want to go outside because I didn't want to look at myself in the mirror. It's not a woman, it's a thing!" Sarah tried to put on more make up but it did not work for her, whereas after taking off the veil she expressed: "I feel this is me, normal, pregnant. I feel peaceful". 45

Karima likewise felt that "playing with her hair" increased her feelings of femininity. In the beginning, she did not know what to do with her hair:

So, I started to play with my hair; to feel more feminine, actually. ( . . . ) Yes, you should not show your femininity. Being feminine means speaking in a soft voice, ... not being so apparent, or you should be very modest and people should hardly notice you. Okay, where is my femininity in that?! Where is the idea of being sexy, or being attractive or anything? All this was to be saved until you get married? ( . . ) But ( . . ) I missed being attractive. I want to be attractive, I want to feel, to put makeup on as I wish. To wear a dress in summer, because it's hot. ${ }^{46}$

40 Interview with author on 12 January 2019.

1 Interview with author on 13 January 2019.

2 Interview with author on 11 January 2019.

3 Interview with author on 12 January 2019.

4 Interview with author on 13 January 2019.

45 Interview with author on 2 July 2013.

46 Interview with author on 12 January 2019. 
Karima clearly expresses her urge to break free from societal norms of femininity and to discover her own femininity. This feeling of desiring to express your uniqueness and femininity was shared by many interlocutors and was narrated as a deeply felt urge to uncover the (feminine) self against all societal and religious odds.

For some, this ownership of their own bodies included having sexual relationships as a "personal right". Agnostic Hayat related this after taking off hijab:

I had the feeling that I returned to my own self (nafsi) once again. I found myself.

I broadened my scope beyond religion and morality and thought about what do

I want or not want; not what God wants me to do or not to do. ( ... ) I did not have sex before I left Islam, because in religion it is forbidden. My thoughts now are: 'It's okay. It is my right'. If ( . . ) I do nothing bad to others, it is your right to do it. Sex is a big problem, you need marriage and agreement of the family but in my present stage I see it as my personal right. It is not even the right of my partner, it's my own right. This is my present way of thinking: what belongs to me is my own right. My body is my own, my mind and my thoughts are my own. My dreams and ambitions in society are mine-especially if it does not damage anyone else. ${ }^{47}$

Although Hayat starts with the right to "own" her body, in the sense of her right to sexuality, it extends to the freedom to shape her own life, having her own thoughts, ambitions and dreams. Some of my interlocutors were able to actualise these dreams and ambitions against societal pressure by being financially independent, engaging in relationships of their own choosing and shaping their own lifestyles. Some unmarried women even managed to live alone or with a roommate, something quite rare in Egypt.

Most of my interlocutors were happy with the changes they had been able to realise for themselves by unveiling. They felt "stronger", "more confident", "more independent" and "courageous" after unveiling. Unveiling particularly involved and brought about a fundamental process of discovering and "finding themselves". In the process of "uncovering the self", they recognised more broadly their own desires and ambitions. Accordingly, unveiling is not only the expression and outcome of the process of uncovering the self, but also became the means by which they developed and fashioned their individual selves and lives.

Heba expressed her ambitions as follows: "I want to be true to myself. I want to be remembered ( . . . ) with this courage when I die: 'Heba was a very courageous person. Heba was true to herself. She was leading a different live, with her friends, her notions ... '." 48 Unveiling is not only an articulation of their self-discovery but also motivates a larger process of exploring who they are and what they want.

\section{Conclusions}

By analysing unveiling in present-day Egypt, this article intends to contribute ethnographically to an 'anthropology of Islam, doubt and (non) religion'. The process of (un)veiling includes deliberations in everyday life about religious normative discourse and practices, as well as resistance and reconsideration of these norms and practices. 'Grand schemes' - in this case the religious discourse of the Egyptian piety movement-and 'the everyday' are not opposed, but integrated into my interlocutors' daily life reflections and choices. This contribution also intends to counterbalance the 'over-Islamisation' in anthropological studies by looking into religious doubt and non-belief, without a priori opposing non-belief to belief. My interlocutors' narratives indicated not only the complexities in the relationship between unveiling and religious identifications, they also showed that it is difficult to draw hard lines between belief and non-belief. Many of them remained spiritual, whether within or beyond the self-defined boundaries of Islam.

47 Interview with author on 15 February 2015. 
Unveiling appears to be a fundamental religious issue and will certainly be perceived as such by many (religious) observers in Egypt. I do not want to deny that unveiling is related to (non)religion, at least during the process of my interlocutors' daily deliberations whether to unveil or not. As demonstrated, for some interlocutors unveiling was part of the process of finding a more spiritual and personal relationship with God, whereas for others it was a staging post in leaving religion altogether.

Yet the religious dimensions only scratch the surface of the profound issues underlying unveiling. My interlocutors' narratives show that unveiling is part of a process of uncovering the self in its manifold aspects. They discover and express their unique personalities, (non) religious identities and their femininity. They express their desire to take ownership of their selves, minds and bodies.

Within the context of social, religious and political pressures weighing on them, they are searching for their own subjectivity. Similar to Mahmood's analysis regarding veiling, we can see that by unveiling they not only express 'the self' but also craft their individuality. Unveiling expresses and brings about transformations in their subjectivities, desires and ambitions. Unveiling is an articulation of-and also sets in motion-a larger process of discovering who they are and what they want. In the process of unveiling, my interlocutors proactively cultivate selfhood. By actively deliberating on "who they are", they reflect on "themselves" and on "the world".

Both my religious and non-religious interlocutors were searching for authentic selfhood, albeit cloaked in different positions regarding Islam. Unveiling challenges normative religion, even if it is motivated by a search for a personalised spirituality. More importantly, my interlocutors share a fundamental motivation to "find themselves" and discover their femininity, their own desires, ambitions and way of living. In opposition to socio-political and religious discourses defining women's subjectivities and desires, they discover their own voice.

By not a priori taking religion as the starting point in the process of unveiling, it was possible to unearth a common fundamental dynamic at play. Crafting selfhood by women challenges the power of the three authoritative pillars in Egypt: religion, politics and the family. Contestation about unveiling is a battle over women's (rebellious) minds and bodies more generally, rather than their religiosity per se. Uncovering the self by unveiling is indeed part of an on-going 'silent revolution'.

Funding: The research was partly funded by University of Kent's Understanding Unbelief programme (https://research.kent.ac.uk/understandingunbelief/).

Institutional Review Board Statement: The study was conducted according to the guidelines of the Declaration of Helsinki, and approved by the Ethics Committee (ETC-GW) of Radboud University, Nijmegen on the 14 June 2017 (no. 9947).

Informed Consent Statement: Informed consent was obtained from all subjects in the study.

Data Availability Statement: The data are not publicly available due to the sensitivity of the topic and protection of the interlocutors.

Conflicts of Interest: The author declares no conflict of interest.

\section{References}

Adang, Camilla, Hassan Ansari, Maribel Fierro, and Sabine Schmidtke, eds. 2016. Accusations of Unbelief in Islam A Diachronic Perspective on Takfïr. Leiden: Brill.

Asad, Talal. 2003. Formations of the Secular: Christianity, Islam, Modernity. Stanford: Stanford University Press.

Bayat, Asef. 2002. Piety, Privilege and Egyptian Youth. ISIM Review 10: 23.

Cottee, Simon. 2015. The Apostates. When Muslims Leave Islam. London: Hurst \& Company.

Cragun, Ryan. T., and Joseph. H. Hammer. 2011. One Person's Apostate is another Person's Convert: What terminology tells us about pro-religious hegemony in the sociology of religion. Humanity \& Society 35: 149-75.

Deeb, Lara. 2006. An Enchanted Modern. Gender and Public Piety in Shi'i Lebanon. Princeton: Princeton University Press.

Ebaugh, H. R. 1988. Becoming an Ex, the process of Role Exit. Chicago: University of Chicago Press.

El-Guindi, Fadwa. 1981. Veiling Infitah with Muslim Ethic: Egypt's Contemporary Islamic Movement. Social Problems 28: 465-85. [CrossRef] 
El-Guindi, Fadwa. 1983. Veiled Activism: Egyptian women in the contemporary Islamic movement. Femmes de la Mediterranee. Peuples Méditerranéens 22-23: 79-89.

Eltahawi, Mona. 2016. Headscarves and Hymens. Why the Middle East Needs a Sexual Revolution. London: Orion Publishing Group.

Enstedt, Daniel. 2018. Understanding religious apostasy, disaffiliation, and Islam in Contemporary Sweden. In Moving in and Out of Islam. Edited by Karin van Nieuwkerk. Austin: University of Texas Press, pp. 67-88.

Enstedt, Daniel, Göran Larsson, and Teemu T. Mantsinen, eds. 2020. Handbook of Leaving Religion. Available online: https:/ / brill.com/ view / title/33911 (accessed on 18 December 2020).

Fadil, Nadia, and Mayanthi Fernando. 2015. Rediscovering the "everyday" Muslim: Notes on an anthropological divide. Journal of Ethnographic Theory 5: 59-88. [CrossRef]

Hafez, Sherine. 2003. An Islam of her Own. Reconsidering Religion and Secularism in Women's Islamic Movements. New York: New York University Press.

Herrera, Linda. 2001. Downveiling: Gender and the Contest over Culture in Cairo. Middle East Report 219: 16-19. [CrossRef]

Hirschkind, Charles. 2006. The Ethical Soundscape. Cassette Sermons and Islamic Counterpublics. New York: Columbia University Press.

Hirschkind, Charles. 2010. Is There a Secular Body? The Immanent Frame, Secularism, Religion, and the Public Sphere. Available online: http:/ / blogs.ssrc.org/tif/2010/11/15/secular-body/ (accessed on 22 June 2012).

Hodgson, Marshall. Goodwin Simms. 1974. The Venture of Islam: Conscience and History in a World Civilization. Chicago: University of Chicago Press.

Hoffman-Ladd, Valerie J. 1987. Polemics on the modesty and segregation of women in contemporary Egypt. International Journal of Middle East Studies 19: 23-50. [CrossRef]

Jouili, Jeanette S., and Schirin Amir-Moazami. 2006. Knowledge, Empowerment and Religious Authority Among Pious Muslim Women in France and Germany. The Muslim World 96: 617-42. [CrossRef]

Larsson, Göran. 2018. Disputed, Sensitive and Indispensable Topics: The Study of Islam and Apostasy. Method and Theory in the Study of Religion 30: 1-26. [CrossRef]

Lee, Lois. 2015. Recognizing the Non-Religious: Reimagining the Secular. Oxford: Oxford University Press.

MacLeod, Arlene Elowe. 1991. Accommodating Protest. Working Women, the New Veiling, and Change in Cairo. New York: Columbia University Press.

Mahmood, Saba. 2001. Feminist theory, embodiment, and the docile agent: Some reflections on the Egyptian revival. Cultural Anthropology 6: 2002-36. [CrossRef]

Mahmood, Saba. 2005. Politics of Piety. The Islamic Revival and the Feminist Subject. Princeton: Princeton University Press.

Makdisi, Usama. 2019. Age of Coexistence. The Ecumenical Frame and the Making of the Modern Arab World. San Francisco: University of California Press.

Marsot, A. Lutfi al-Sayyid. 1984. Religion or Opposition? Urban Protest Movements in Egypt. International Journal of Middle East Studies 16: 541-52. [CrossRef]

Noor, Sahar. 2017. Creating a Female Islamic Space. Piety, Islamic Knowledge and Religious Authority among Born-Muslims and Converts to Islam in the Netherlands and Belgium. Ph.D. thesis, Radboud University Nijmegen, Nijmegen, The Netherlands.

Olsson, Susanne. 2008. Apostasy in Egypt: Contemporary Cases of Hisbah. The Muslim World 98: 95-116. [CrossRef]

Pelkmans, M., ed. 2013. Ethnographies of Doubt. Faith and Uncertainty in Contemporary Societies. London and New York: I. B. Tauris.

Schielke, Samuli. 2009. Being good in Ramadan: Ambivalence, fragmentation and the moral self in the lives of young Egyptians. Journal of the Royal Anthropological Institute 15: 24-40. [CrossRef]

Schielke, Samuli. 2010. Second Thoughts about the Anthropology of Islam, or How to Make Sense of Grand Schemes in Everyday Life. Working Papers. Berlin: Zentrum Moderner Orient, vol. 2, pp. 1-16.

Schielke, Samuli. 2012. Being a Nonbeliever in a time of Islamic Revival: Trajectories of Doubt and Certainty in Contemporary Egypt. International Journal of Middle East Studies 44: 301-20. [CrossRef]

Schielke, Samuli. 2013. The Islamic World. In The Oxford Handbook of Atheism. Edited by Stephen Bullivant and Michael Ruse. Oxford: Oxford University Press, pp. 638-51.

Schielke, Samuli, and Liza Debevec, eds. 2012. Introduction. In Ordinary Lives and Grand Schemes: An Anthropology of Everyday Religion. New York: Berghahn.

Streib, Heinz. 2014. Deconversion. In The Oxford Handbook of Religious Conversions. Edited by L. R. Rambo and C. E. Farhadian. Oxford: Oxford University Press.

Van Nieuwkerk, Karin. 2013. Performing Piety. Singers and Actors in Egypt's Islamic Revival. Austin: University of Texas Press.

Van Nieuwkerk, Karin, ed. 2018a. Introduction Moving in and out of Islam. In Moving in and Out of Islam. Austin: University of Texas Press, pp. 1-24.

Van Nieuwkerk, Karin, ed. 2018b. Religious Skepticism and Nonbelieving in Egypt. In Moving in and Out of Islam. Austin: University of Texas Press, pp. 306-33.

Van Nieuwkerk, Karin, ed. 2018c. The Concealment of Apostasy among Ex-Muslims in Britain and Canada. In Moving in and Out of Islam. Austin: University of Texas Press, pp. 281-306.

Van Nieuwkerk, Karin. 2021a. The Atheist Spring? Emerging Unbelief in the Islamic World. In History of Atheism. Cambridge: Cambridge University Press. 
Van Nieuwkerk, Karin. 2021b. Closet cultures of unbelief in Egypt. Former Muslims' voices. In Cultures of Unbelief. Oxford: Oxford University Press.

Vliek, Maria. 2020. Neither in nor Out. Former Muslims between Narratives of Belonging and Secular Convictions in the Netherlands and the UK. Ph.D. thesis, Radboud University Nijmegen, Nijmegen, The Netherlands.

Whitaker, Brian. 2014. Arabs without God. Atheism and freedom of belief in the Middle East. Scotts Valley: CreateSpace.

Wise, Lindsay. 2003. 'Words from the Heart': New Forms of Islamic Preaching in Egypt; M. Phil Oxford University. Available online: http:/ / users.ox.ac.uk/ \{\}metheses/Wise.html (accessed on 18 December 2020).

Zuhur, Sherifa. 1992. Revealing Reveiling: Islamist Gender Ideology in Contemporary Egypt. Albany: State University of New York Press. 